\title{
Significance of Halimeda bioherms to the global carbonate budget based on a geological sediment budget for the Northern Great Barrier Reef, Australia
}

Received: 9 October 2005/ Accepted: 18 October 2006/Published online: 17 November 2006

(C) Springer-Verlag 2006

\begin{abstract}
Since the correlation between carbon dioxide $\left(\mathrm{CO}_{2}\right)$ levels and global temperatures was established in the ice core records, quantifying the components of the global carbon cycle has become a priority with a view to constraining models of the climate system. The marine carbonate budget is still not adequately constrained and the quantitative significance of the calcareous green alga Halimeda still remains particularly poorly understood. Previously, it has been suggested that Halimeda bioherms on the shelf of the Great Barrier Reef may contain a volume of carbonate equal to or greater than that contained within the shelf edge coral reefs. This study uses published datasets to test this hypothesis in the Northern Great Barrier Reef (NGBR) province. It is estimated that Halimeda bioherms on the outer shelf of the NGBR contain at least as much (and up to four times more) $\mathrm{CaCO}_{3}$ sediment as the adjacent ribbon reef facies. Globally, if these findings are even only partially applicable, that contribution of shallow water carbonate sediments to the global carbon budget based on coral reefs alone is currently substantially underestimated.
\end{abstract}

Keywords Halimeda bioherms · Holocene · Calcium carbonate budget

Communicated by Geology Editor P.K. Swart.

\footnotetext{
S. A. Rees $(\bowtie) \cdot$ P. A. Wilson · T. J. Henstock National Oceanography Centre, Southampton, European Way, Southampton SO14 3ZH, UK E-mail: Sar1@noc.soton.ac.uk

Tel.: + 44-23-80596108

Fax: + 44-23-80593052

B. N. Opdyke

Earth and Marine Sciences Department, Building 47, Australian National University, Canberra,

ACT 0200, Australia
}

\section{Introduction}

Carbonate budgets

The role of neritic carbonate within the global carbon cycle is yet to be adequately quantified (Ridgwell and Zeebe 2005). Documenting the loci and rates of carbonate production and accumulation during the Holocene is the key to quantifying the shallow water carbonate budget (Milliman 1993). Recently, it has been estimated that coral reefs have accumulated approximately $7,970 \mathrm{Gt} \mathrm{CaCO}_{3}$ over the last 10,000 years before present ( $\mathrm{kyr} \mathrm{BP}$; i.e. $0.8 \mathrm{Gt} \mathrm{CaCO}_{3}$ year $^{-1}$; Rees 2006). It is widely accepted that the calcareous green alga Halimeda is a prominent contributor of carbonate to reef sediment facies in the tropics, but the significance to the global carbonate budget of distinct Halimeda bioherms, independent of coral reefs, is poorly known (Hillis-Colinvaux 1980; Drew and Abel 1983; Phipps et al. 1985; Milliman 1993; Freile et al. 1995; Hillis 1997; Steneck and Testa 1997).

Milliman (1993) estimated that modern Halimeda bioherms accumulate approximately $0.15 \mathrm{Gt} \mathrm{CaCO}_{3}$ year $^{-1}$ globally. This figure was based on estimated numbers of Halimeda meadow crops per year and the assumption that, globally, bioherms cover an area of $5 \times 10^{4} \mathrm{~km}^{2}$. Hillis (1997) attempted a first budget for modern day Halimeda meadows using the estimates for lagoon, ridge and bioherm area and Halimeda crops per year taken from the studies of Smith and Kinsey (1976), Smith (1978) and Milliman (1993). On this basis, Hillis (1997) calculated a modern global Halimeda bioherm production of $0.4 \mathrm{Gt} \mathrm{CaCO}_{3}$ year $^{-1}$, approximately $83 \%$ of coral reef carbonate production. Despite these early attempts to determine a Halimeda carbonate budget, the global distribution, aerial extent and role of Halimeda in the global carbon cycle have yet to be precisely quantified for both the present day and the past (Milliman 1993; Rees et al. 2005). 


\section{Halimeda}

Halimeda is a genus of macroscopic calcareous green algae (Order Caulepales; Chlorophyta; Hillis 1997; Heyward et al. 1997). The bushy plants are composed of numerous calcified $\left(60-80 \% \mathrm{CaCO}_{3}\right)$ flat segments between 0.5 and $3 \mathrm{~cm}$ wide that are joined at un-calcified nodes (Drew 1993). The calcified segments are shed as part of the growth and senescence cycle by disintegration of the nodes (Drew 1993; Hillis 1997). Halimeda are found in a variety of habitats from mangrove prop roots to the reef front zone on coral reefs, and Halimeda meadows create complex habitats that serve as refuges, nursery grounds and food for a variety of organisms (Hillis-Colinvaux 1986a; Hillis 1997; Steneck and Testa 1997; Heyward et al. 1997). Halimeda originated in the Cretaceous and are thought to have contributed to reef sediments for at least the last 65 million years (Elliot 1965; Johnson 1969; Hillis-Colinvaux 1980; Hillis 1997). In fact, it has been proposed that modern bioherms are reminiscent of phylloid algal bioherms of late Paleozoic reefs that presently act as hydrocarbon reservoirs (Ball et al. 1977; Wray 1977; Drew and Abel 1988; Kirkland et al. 1993). A variety of terms have been used to describe the range of different structures created by Halimeda sediments (Table 1).

\section{Halimeda bioherms}

Significant accumulations of Halimeda debris have been found worldwide. Actively accreting Halimeda bioherms have been described in exposed and protected environments in the Eastern Java Sea, Indonesia on Kalukalukuang Bank (K bank) (Roberts et al. 1987a, b, 1988; Phipps and Roberts 1988). These bioherms are approximately $20-30 \mathrm{~m}$ thick, locally $50 \mathrm{~m}$ high and are commonly $10 \mathrm{~km}$ wide. Vibrocores reveal that these structures are composed of Halimeda packstone with foraminifera-rich carbonate mud and exhibit rapid accumulation rates in the region of 3-6 $\mathrm{m} \mathrm{kyr}^{-1}$ (Roberts et al. 1987a, b; Roberts and Phipps 1988). Similarly, Hine et al. (1988) discovered extant Halimeda bioherms $20-30 \mathrm{~m}$ in height (some reaching as high as $140 \mathrm{~m}$ ) that form an almost continuous band, approximately $125 \mathrm{~km}$ long, in water depths of $40-50 \mathrm{~m}$ in the Southwest Caribbean (Nicaraguan Rise, Miskito Channel). These banks are composed of coarse poorly cemented packstones and grainstones of dead disarticulated Halimeda segments with a living veneer on top. Halimeda rich gravel deposits up to $15 \mathrm{~m}$ in relief with accumulation rates averaging $0.2 \mathrm{~m} \mathrm{kyr}^{-1}$ have also been described on the Fly River Delta, Gulf of Papua New Guinea (Harris et al. 1996). A series of eight submerged carbonate platforms, that range in size from 0.05 to $40 \mathrm{~km}^{2}$, in the Timor Sea, North Western Australia are dominated by Halimeda bank deposits (Heyward et al. 1997). Cores from these banks reveal that over $80 \%$ of the total sediment is Halimeda debris.

\section{Coral reefs}

Ribbon reefs are the barrier reefs along the edge of the Australian continental shelf, they form an almost continuous narrow high wall interrupted by narrow channels. For the purpose of this study a ribbon reef is defined as a three-dimensional structure comprised of calcium carbonate sediment (rock, sands and muds) generated by scleractinian coral and coralline algae calcification occurring in a tropical environment which remains as solid $\mathrm{CaCO}_{3}$ and is not dissolved (Rees et al. 2005). This definition excludes terrigenous sediments and non-reef habitats including banks, platforms and carbonate dominated embayments. Reefs within the Great Barrier Reef (GBR) province vary considerably in size and form, Holocene reef growth is represented by only a thin veneer, 10-20 m thick, commonly on top of karstified Pleistocene substrates (Davies et al. 1977; Hopley 1982). These investigations reveal that the Holocene ribbon reefs of the Lizard Island and Cooktown regions are approximately 9.5 and $15 \mathrm{~m}$ thick, respectively.

\section{Study area}

The GBR, a high energy epi-continental shelf edge reef system, is the largest reef system in the world covering an area of approximately $49,000 \mathrm{~km}^{2}$ and comprises nearly 3,000 individual reefs (Fig. 1; Davies and Marshall 1980; Spalding et al. 2001). The northern province of the GBR extends from $9^{\circ} \mathrm{S}$ to $16^{\circ} \mathrm{S}$, is generally narrow, between 24 and $60 \mathrm{~km}$ wide and is the shallowest

Table 1 Terms used to describe Halimeda sediment formations

\begin{tabular}{|c|c|c|c|}
\hline Term & Definition & Reference & Year \\
\hline Bioherms & $\begin{array}{l}\text { Mounds which have relief above the sea floor but which do not exhibit } \\
\text { a clear framework and which exist in a relatively low energy } \\
\text { environment }\end{array}$ & Davies and Marshall & 1985 \\
\hline Meadow & Inter-reefal areas of luxuriant Halimeda vegetation & Drew and Abel & 1988 \\
\hline Mounds or banks & $\begin{array}{l}\text { Discrete circular mounds of Halimeda debris that sometimes } \\
\text { coalesce into ridges }\end{array}$ & Drew and Abel & 1988 \\
\hline Drapery & $\begin{array}{l}\text { Vertical meadow of loose sprawling plants that hang over the } \\
\text { cemented escarpment ledges }\end{array}$ & Freile et al. & 1995 \\
\hline
\end{tabular}




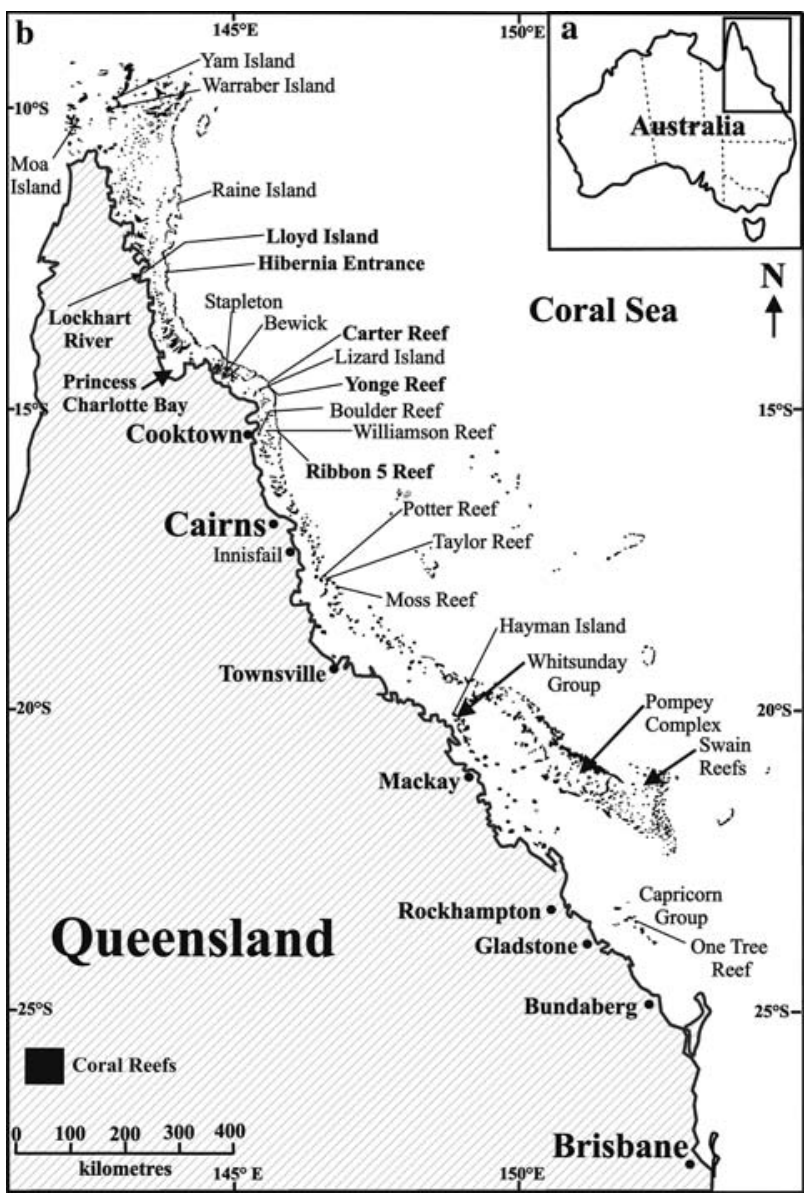

Fig. 1 a Australia showing location of the Great Barrier Reef (GBR) (modified after Flood 1984). b The GBR. The majority of Halimeda meadows are located between the latitudes of $10^{\circ} 30^{\prime} \mathrm{S}$ and $15^{\circ} 35^{\prime} \mathrm{S}$ (Far Far North GBR to Northern Great Barrier Reef)

part of the GBR with depths commonly $<40$ m below sea level (Maxwell 1968; Orme and Flood 1980; Orme 1985). This region of the Northern Great Barrier Reef (NGBR) is characterised by an almost continuous line of shelf edge ribbon reefs, varying from 3 to $26 \mathrm{~km}$ in length and between 300 and $450 \mathrm{~m}$ wide (Orme and Flood 1977, 1980; Kinsey 1979; Flood 1984). The Lizard Island region is located approximately $270 \mathrm{~km}$ north of Cairns (Fig. 2; Flood 1984). This area of the GBR province has a north-south trending line of granite continental islands (Lizard Island; North Direction Island and South Direction Island) which are surrounded by fringing reefs. The Cooktown region lies directly east of Cooktown itself and $180 \mathrm{~km}$ north of Cairns, it is characterised by a line of ribbon reefs along the shelf edge and platform reefs of various shapes and sizes across the shelf (Fig. 3).

\section{Halimeda bioherms of the GBR}

Maxwell (1968) estimated that approximately 10-30\% of the reef surface in the GBR is composed of Halimeda rubble and that $5-65 \%$ of the inter-reefal sediments are derived from Halimeda. The majority of Halimeda bioherms are located between the latitudes of $10^{\circ} 30^{\prime} \mathrm{S}$ and $15^{\circ} 35^{\prime} \mathrm{S}$ (Far Far North GBR to NGBR) on the outer shelf at depths of between 20 and $40 \mathrm{~m}$ below sea level (Fig. 1b; Drew and Abel 1983, 1988). Seismic profiling studies have revealed the absence of Halimeda bioherm deposits in the Princess Charlotte Bay and Bathurst Bay areas, just north of Lizard Island (Fig. 1b; Orme 1983, 1985). Further north, however, seismic profiles reveal the presence of bioherms in the region adjacent to Lloyd Bay and the Lockhart River, between North Lloyd Island and Hibernia Entrance and between Restoration Island and Second Small Reef $\left(12^{\circ} 47^{\prime}\right.$ S, Fig. 1b; J.S. Jell, personal communication). Halimeda deposits, 1.5-14 m thick, have also been found within the Swains Reef Complex $\left(20^{\circ} 53^{\prime} \mathrm{S}-22^{\circ} 24^{\prime} \mathrm{S}\right)$ of the Southern GBR (Maxwell 1973; Searle and Flood 1988). Radiocarbon dating of sediments from the top $4.3 \mathrm{~m}$ of the Swains Reef bioherms reveal accretion rates of between 2 and $3.5 \mathrm{~m} \mathrm{kyr}^{-1}$ during the last 5,000 years (Searle and Flood 1988).

Halimeda bioherms have been investigated in detail using seismic profiling, echo sounding, vibro and piston coring and grab sampling in two regions of the Northern GBR, Lizard Island and Cooktown (Figs. 2, 3; Orme et al. 1978; Orme 1985; Davies and Marshall 1985; Phipps et al. 1985; Orme and Salama 1988; Marshall and Davies 1988). Seismic investigations in the Lizard Island region (between latitudes of $14^{\circ} 27^{\prime} \mathrm{S}$ and $15^{\circ} 02^{\prime} \mathrm{S}$ ) reveal extensive Halimeda bioherms behind the ribbon reefs. These bioherms are up to $6 \mathrm{~km}$ wide, $100 \mathrm{~km}$ long and can reach thicknesses of $18.5 \mathrm{~m}$ at a depth of $25 \mathrm{~m}$ below sea level (Fig. 2; Orme et al. 1978; Orme 1983; Flood and Orme 1988; Orme and Salama 1988). The bioherms are composed of Halimeda packstones and wackstones, reach maximum thickness of $18.5 \mathrm{~m}$ in the east but are less well developed in the west. The bioherms in the Lizard Island region are formed of ridges and mounds separated by hollows and channels and living Halimeda vegetation is found on the tops of the bioherms. Radiocarbon dating of a peat surface immediately below the bioherms reveals that they were formed during the Holocene (radiocarbon age of a peat sample 10,070 \pm 180 years BP) and growth was initiated some 1,500 years before the nearby ribbon reefs (Orme 1985).

On the outer shelf east of Cooktown (between latitudes $15^{\circ} 10^{\prime} \mathrm{S}$ and $15^{\circ} 46^{\prime} \mathrm{S}$ ) discrete biohermal complexes are found lying $1-2 \mathrm{~km}$ directly behind the ribbon reefs (Fig. 3; Davies and Marshall 1985; Marshall and Davies 1988). Individual bioherms can cover an area of several kilometres square and are composed of numerous subconical mounds (100-250 m wide) of unconsolidated sediments between 15 and $20 \mathrm{~m}$ in relief (Marshall and Davies 1988; Wolanski et al. 1988). The tops of the bioherms are covered by a forest of green algae (Caulpera and Halimeda) which effectively traps and stabilises the sediment. Radiocarbon dating of vibrocored sedi- 
Fig. 2 Lizard Island region, Northern Great Barrier Reef. Area enclosed by grey dashed lines indicates the extent of Halimeda bioherms revealed by seismic profiling (adapted from Orme et al. 1978; Orme 1983; Orme and Salama 1988), the grey stippled area indicates the area of bioherm coverage which averages $10 \mathrm{~m}$ thickness and was used in the calculations herein (modified after Admiralty Chart Aus 373)

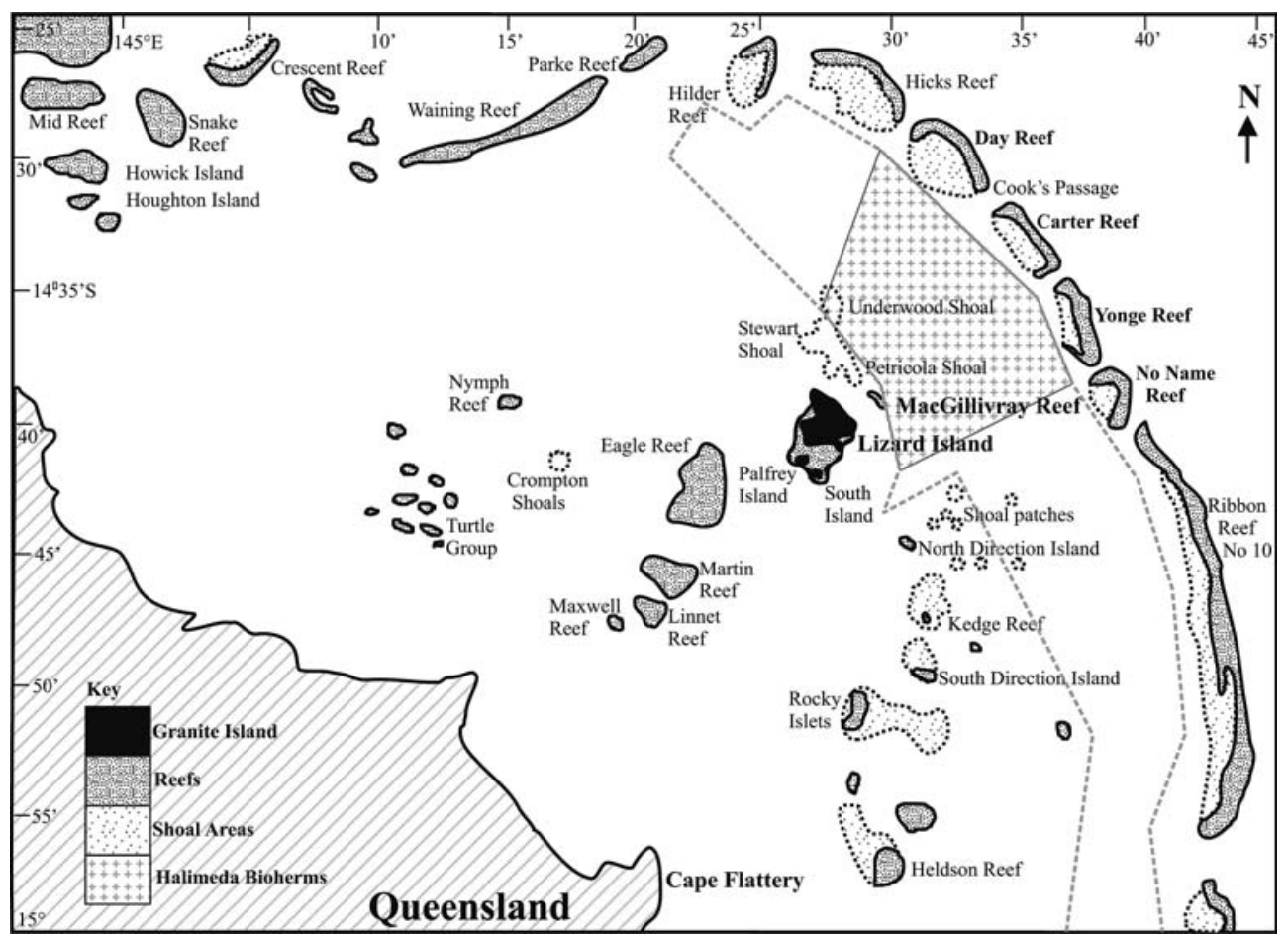

Fig. 3 Cooktown region, Northern Great Barrier Reef, grey stippled areas indicate locations of Halimeda bioherms; North Bank and Ribbon Banks 2-5 (modified after the Great Barrier Reef Marine Park Authority Map BRA Q 155 February 1992)

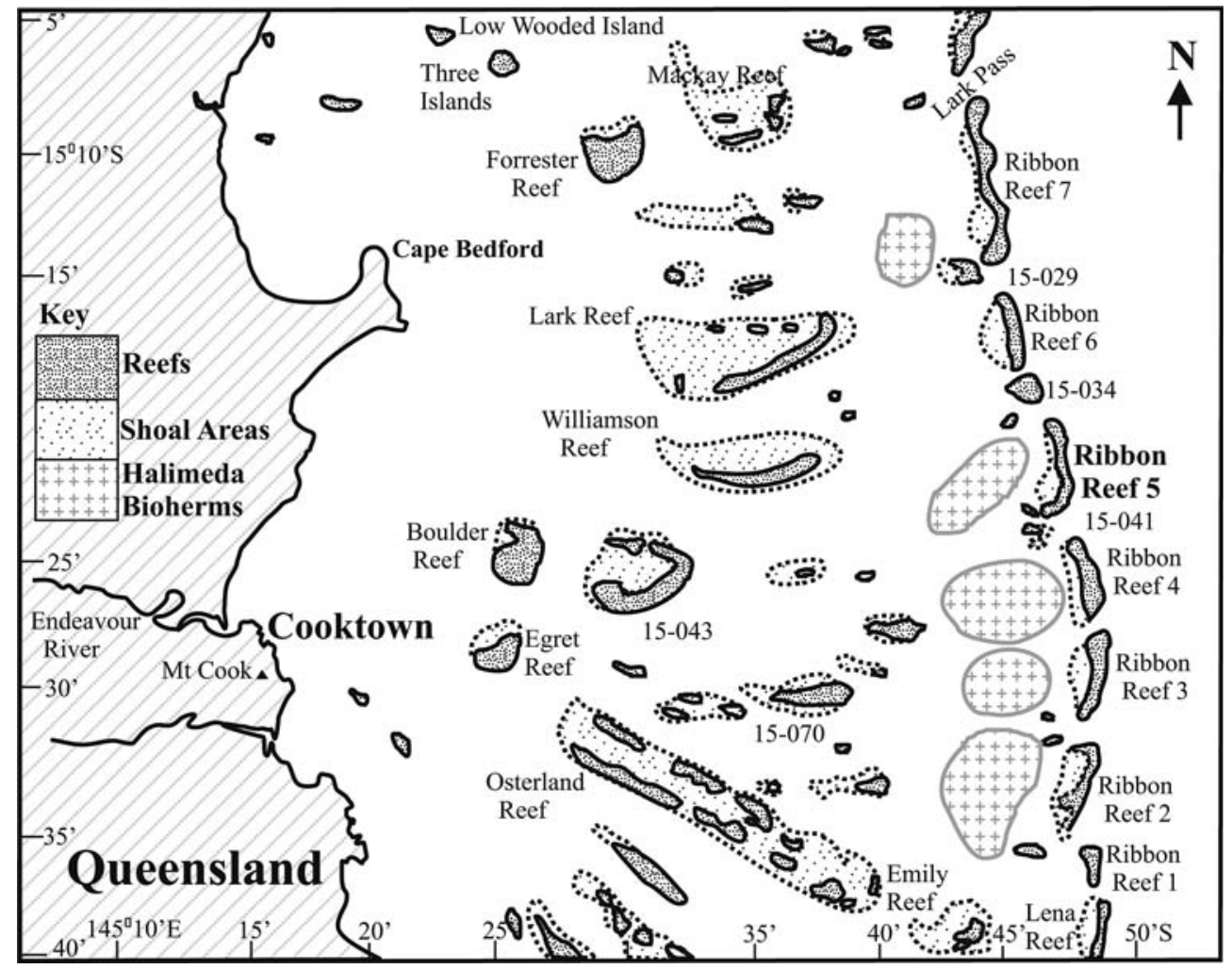

ments reveals that the bioherms are still actively accreting and that vertical accretion rates have ranged between 1 and $3 \mathrm{~m} \mathrm{kyr}^{-1}$ during the last 5,000 years. The bioherms are composed dominantly of Halimeda.
Cores extracted from the bioherms reveal a carbonate content averaging $75 \%$, the remaining $25 \%$ is comprised fine grained terrigenous material (Marshall and Davies 1988). 
In summary, the Halimeda bioherms of the NGBR are restricted to outer shelf areas, have thicknesses, accretion and productivity rates comparable to and cover areas larger than individual coral reefs (Davies and Marshall 1979; Drew 1983; Drew and Abel 1983; Marshall and Davies 1988). It has been suggested that the mass of $\mathrm{CaCO}_{3}$ sediment within the Halimeda bioherms may be greater than those of the adjacent shelf edge reefs (Flood 1984; Hillis 1997).

\section{Mechanism of formation}

The mechanisms of Halimeda bioherm formation are still debated. The Halimeda bioherms in the NGBR are thought to have been formed because jets of up-welled nutrient-rich oceanic water intruded onto the outer shelf through the narrow passages between the ribbon reefs and formed eddies in the relative shelter behind the reefs (Drew and Abel 1985; Marshall and Davies 1988). The absence of Halimeda bioherms in the Princess Charlotte Bay region is probably related to the input of fluvial mud from the Normandy River system, which reduces light levels and smothers vegetation (Drew and Abel 1988). In the Southern GBR Halimeda deposits in the Swains Reef Complex have been associated with an influx of nutrientrich water onto the platform as a result of convergence of the ocean currents from the Capricorn Channel and the Coral Sea (Maxwell 1968; Searle and Flood 1988).

\section{Materials and methods}

To quantify the relationship between Halimeda and coral reef-derived carbonate accumulated during the Holocene on the outer shelf of the NGBR this study used data derived from seismic profiling, reef drill cores and Halimeda bioherm piston and vibrocore cores taken from the published literature (Orme et al. 1978; Davies and Hopley 1983; Davies et al. 1985; Davies and Marshall 1985; Orme 1985; Marshall and Davies 1988; Orme and Salama 1988; Wolanski et al. 1988). The volume of carbonate sediment within Halimeda bioherms was compared with the adjacent ribbon reefs for the following reasons. The presence of ribbon reefs is believed to be essential for Halimeda bioherm development within the NGBR (Wolanski et al. 1988). It would not be appropriate to compare the volume of carbonate sediment within mid-shelf reefs with that within the Halimeda bioherms because mid-shelf reefs contain variable volumes of terrigenous sediment whereas the ribbon reefs contain little terrigenous sediment. To extrapolate the proportion of carbonate within the Halimeda bioherms to the rest of the NGBR it was necessary to select a reef type which is a consistent feature of the NGBR. The number and type of mid-shelf reef varies considerably within that NGBR province whereas ribbon reefs are a consistent feature of the NGBR.

\section{Reef calcium carbonate}

The mass of $\mathrm{CaCO}_{3}$ for the ribbon reefs in each region was estimated using Eq. 1.

$M=((A \times T) \times 2) \times D \times P \times C$

where $M$ is the mass of carbonate sediments; $A$ is reef area $\left(\mathrm{km}^{2}\right)$ estimated using a $1-\mathrm{km}^{2}$ grid (Fig. 4$) ; T$ is the average thickness of the Holocene ribbon reefs (m); 2 is the factor used to correct reef mass for material exported to the leeward accretionary wedge and lagoon facies (Ryan et al. 2001). $D$ is the density of coral reef $\mathrm{CaCO}_{3}$ (2.9 $\mathrm{g} \mathrm{cm}^{-3}$; Kinsey and Hopley 1991); $P$ is the average porosity of coral reef sediments (50\%; Ryan et al. 2001); $C$ is the average carbonate content of coral reef sediments, this term can effectively be ignored because the carbonate content of coral reefs is assumed to be $100 \%$. The mass of ribbon reef $\mathrm{CaCO}_{3}$ estimated by Eq. 1 is shown in Table 2.

\section{Reef area and thickness}

A $1-\mathrm{km}^{2}$ grid was used to estimate the area of the ribbon reefs in both the Lizard Island and Cooktown regions from the GBR Marine Park Authority map BRA Q 155 February 1992 (Figs. 2, 4). The areas of the ribbon reefs in the Lizard Island and Cooktown regions were esti-

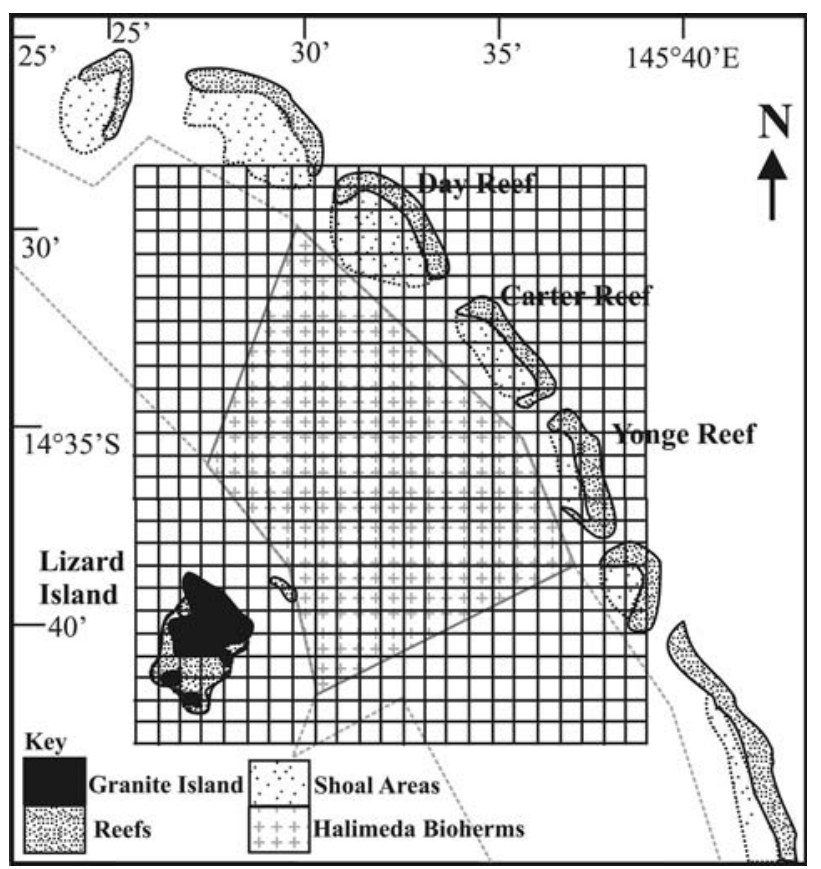

Fig. 4 Schematic diagram showing the estimation of the area covered by the Halimeda bioherms and the coral reefs in the Lizard Island region using a $1-\mathrm{km}^{2}$ grid. The grey dashed line indicates the area on the outer shelf where Halimeda bioherms are present, the grey stippled area indicates the area where the bioherms are at least $10 \mathrm{~m}$ thick. The black heavily stippled areas indicate the shallow coral reef flats 
Table 2 Dimensions and mass of ribbon reef $\mathrm{CaCO}_{3}$

\begin{tabular}{|c|c|c|c|c|}
\hline Region & $\begin{array}{l}\text { Ribbon } \\
\text { reef }\end{array}$ & $\begin{array}{l}\text { Reef } \\
\text { area }\left(\mathrm{km}^{2}\right)\end{array}$ & $\begin{array}{l}\text { Thickness } \\
\text { (m) }\end{array}$ & $\begin{array}{l}\text { Mass } \\
\mathrm{CaCO}_{3}(\mathrm{Gt})\end{array}$ \\
\hline \multirow[t]{3}{*}{ Lizard Island } & Day & 5.75 & 9.5 & 0.16 \\
\hline & Carter & 5.75 & 9.5 & 0.16 \\
\hline & Yonge & 6.75 & 9.5 & 0.19 \\
\hline Total & & 18.5 & & 0.52 \\
\hline \multirow[t]{6}{*}{ Cooktown } & Ribbon 5 & 5 & 15 & 0.22 \\
\hline & Ribbon 4 & 5 & 15 & 0.22 \\
\hline & Ribbon 3 & 4.5 & 15 & 0.2 \\
\hline & Ribbon 2 & 5 & 15 & 0.22 \\
\hline & $15-072$ & 0.25 & 15 & 0.01 \\
\hline & $15-073$ & 0.75 & 15 & 0.03 \\
\hline Total & & 20.5 & & 0.92 \\
\hline
\end{tabular}

mated to be 18.5 and $20.5 \mathrm{~km}^{2}$, respectively (Fig. 4; Table 2).

Drilling, radiocarbon dating and seismic profiling investigations across the outer ribbon reefs, Carter and Yonge (15 km east of Lizard Island) have revealed that these reefs reached modern sea level by approximately 5,800 and 5,200 years BP, respectively, and that modern sea level was reached by 5,500 years BP (Harvey 1977a; Hopley 1994). The Holocene-Pleistocene unconformity lies at approximately $19.3 \mathrm{~m}$ below the reef flat of the back reef at Yonge Reef and $19 \mathrm{~m}$ below the reef flat of the leeward edge of Carter Reef (Harvey 1977a, b; Hopley 1977, 1994). Seismic profiling also has revealed discontinuity surfaces at about $10 \mathrm{~m}$ below the reef flat on the windward margins of Carter reef and two midshelf reefs, Nymph and Three Isle (Figs. 2, 3; Harvey 1977a, b; Orme et al. 1978).

Immediately east of Cooktown itself, a transect of reefs has been drilled including Boulder Reef, Williamson Reef and Ribbon Reef 5 (Fig. 3; Davies et al. 1985; International Consortium for Great Barrier Reef Drilling 2001). Radiocarbon dating has indicated that reef growth in this region was initiated between 6,300 and 8,400 years BP on Pleistocene foundations at depths ranging from 15 to $17 \mathrm{~m}$ below the reef flat. Modern day sea level was established in this region by 6,500 years BP and the reefs reached modern day sea level between 5,900 and 6,700 years BP (Thom and Chappell 1975; Stoddart et al. 1978; Chappell et al. 1983).

The thickness of the Holocene ribbon reefs was estimated from drill cores for the Cooktown region (Davies et al. 1985) and from both drill cores and seismic profiling studies in the Lizard Island region (Davies et al. 1977; Hopley 1977, 1994). These studies reveal that the average thickness of the Holocene ribbon reefs is 15 and $9.5 \mathrm{~m}$ for the Cooktown and Lizard Island regions, respectively.

\section{Halimeda calcium carbonate}

The mass of Halimeda bioherm $\mathrm{CaCO}_{3}$ for both regions was estimated using Eq. 2.
$M=A \times T \times D \times P \times C$

where $M$ is the mass of carbonate sediments; $A$ is bioherm area $\left(\mathrm{km}^{2}\right) ; T$ is the average thickness of the $\mathrm{Hal}$ imeda bioherms (m); $D$ is the average density of $\mathrm{CaCO}_{3}$ (2.9 $\mathrm{g} \mathrm{cm}^{-3}$; Kinsey and Hopley 1991); $P$ is the porosity of the bioherm sediment which is assumed to be $50 \%$; $C$ is the average carbonate content of the Halimeda bioherms (75\%; Orme 1985; Marshall and Davies 1988).

\section{Lizard Island region bioherm area and thickness}

To estimate the mass balance of Halimeda bioherm $\mathrm{CaCO}_{3}$ it was necessary to approximate their area using data from seismic profiling, echo sounding and grab sampling studies of the Lizard Island area (Orme et al. 1978; Orme 1985) and Cooktown regions (Davies and Marshall 1985; Phipps et al. 1985; Marshall and Davies 1988; Wolanski et al. 1988). The area covered by the bioherms in the study area is harder to assess because they form a series of sinuous ridges and banks that effectively blankets the outer shelf. Thicknesses of sediment vary from 4 to $19 \mathrm{~m}$ over relatively short distances but the majority of the bioherms are between 10 and $19 \mathrm{~m}$ thick, averaging $14.5 \mathrm{~m}$ thick (Orme et al. 1978; Orme 1985; Orme and Salama 1988). Estimating the areal extent of the bioherms is also hampered by the sparsity of published seismic profiles. A $1-\mathrm{km}^{2}$ grid was used to estimate the area of bioherms which are consistently reported to have a thickness of $10 \mathrm{~m}$ or more (Figs. 2, 4). It is estimated that the areas occupied by Halimeda bioherms are at least 184 and $118 \mathrm{~km}^{2}$ for the Lizard Island and Cooktown regions, respectively (Fig. 4; Table 3). It is conservatively assumed that the average thickness of the Halimeda deposits in the Lizard Island region is $10 \mathrm{~m}$ (Table 3 ).

\section{Cooktown region bioherm area and thickness}

Halimeda bioherms in the Cooktown region appear to form more or less discrete mounds behind each of the ribbon reefs. The average thickness of each bioherm in the Cooktown region was estimated from seismic and echo sounding profiles and descriptions in the published literature (Fig. 5; Davies and Marshall 1985; Phipps et al. 1985; Marshall and Davies 1988). To interpret the seismic profiles which display the thickness of sediment in milliseconds, a figure of $1,500 \mathrm{~ms}^{-1}$ was used to represent the velocity of the acoustic pulse following the methods of previous authors (Orme et al. 1978; Ryan et al. 2001). The thickness of each of the bioherms is not uniform. To take into account the variation in bioherm thickness, the bioherms were spilt into boxes (Fig. 5). For example, half of the area of a bioherm may be approximately $11.25 \mathrm{~m}$ thick, whereas the other half may be only $3.75 \mathrm{~m}$ thick (Ribbon Bank 3; Table 3). The mass of sediment was calculated by assuming that the 
Table 3 Dimensions and mass of Halimeda bioherm $\mathrm{CaCO}_{3}$

\begin{tabular}{|c|c|c|c|c|}
\hline Region & $\begin{array}{l}\text { Bioherm } \\
\text { complex }\end{array}$ & $\begin{array}{l}\text { Area } \\
\left(\mathrm{km}^{2}\right)\end{array}$ & $\begin{array}{l}\text { Thickness } \\
\text { (m) }\end{array}$ & $\begin{array}{l}\text { Mass } \\
\mathrm{CaCO}_{3}(\mathrm{Gt})\end{array}$ \\
\hline Lizard Island & $\begin{array}{l}\text { Lizard Island } \\
\text { region }\end{array}$ & 184 & 10 & 2.06 \\
\hline Total & & 184 & & 2.06 \\
\hline \multirow[t]{8}{*}{ Cooktown } & Ribbon 5a & 8.4 & 8.25 & 0.07 \\
\hline & Ribbon $5 b$ & 9.1 & 3.75 & 0.04 \\
\hline & Ribbon 4a & 21 & 6 & 0.14 \\
\hline & Ribbon 4b & 14 & 3.75 & 0.06 \\
\hline & Ribbon 3a & 12.5 & 11.25 & 0.16 \\
\hline & Ribbon 3b & 12.5 & 3.75 & 0.05 \\
\hline & Ribbon $2 \mathrm{a}$ & 20 & 11.25 & 0.25 \\
\hline & Ribbon $2 b$ & 20 & 3.75 & 0.08 \\
\hline Total & & 118 & & 0.86 \\
\hline
\end{tabular}

bioherm sediments approximate a box shape with the area of each bioherm (width $\times$ length) multiplied by the corresponding thickness (Fig. 5). Some bioherms were split into two boxes to estimate the appropriate volume of the bioherms as a whole, e.g. Ribbon 3a, 2b (Fig. 5; Table 3).

\section{Carbonate content}

The carbonate content of the bioherms has been investigated by vibrocoring studies in both the Lizard Island and Cooktown regions (Orme 1985; Marshall and Davies 1988). Marshall and Davies (1988) estimated, from twenty 5-m vibrocores taken in the Cooktown region, that the carbonate content within the bioherms averages approximately $75 \%$. Four vibrocores from the Lizard Island region revealed that the carbonate content (acid soluble) within the top $4 \mathrm{~m}$ of the bioherms varies between 73 and 99\% (Orme 1985). A fifth core taken from the edge of one of the bioherms revealed that the carbonate content of the bioherms increases progressively upwards above the peat substratum, varying between 20 and $90 \%$ (core 92; Orme 1985). This core is marginal
Fig. 5 a Seismic profile of Halimeda bioherm, Ribbon Bank 3, behind Ribbon Reef 3 in the Cooktown region [modified from Marshall and Davies 1988 (Fig. 2, profile b)]. The black dashed rectangles ( $3 a$ and $3 b$ ) outlines how Ribbon Bank 3 was split into two boxes in order to calculate the volume of carbonate sediment. b The mass of sediment was conservatively estimated by assuming that the bioherm sediments approximate a box shape with the area of each bioherm $(L \times W)$ multiplied by the corresponding thickness $(T)$. c The volume of $3 a$ was calculated by multiplying the area $\left(L_{\mathrm{a}} \times W ; 12.5 \mathrm{~km}^{2}\right)$ by the thickness of the bioherm ( $T$, $11.25 \mathrm{~m}$; Table 3). d The volume of $3 b$ was calculated by multiplying the area $\left(L_{\mathrm{b}} \times W\right.$; $12.5 \mathrm{~km}^{2}$ ) by the thickness of the bioherm $\left(T_{\mathrm{b}}, 3.75 \mathrm{~m}\right.$; Table 3). The volume of Ribbon Bank 3 is calculated as the sum of boxes $3 a$ and $3 b$
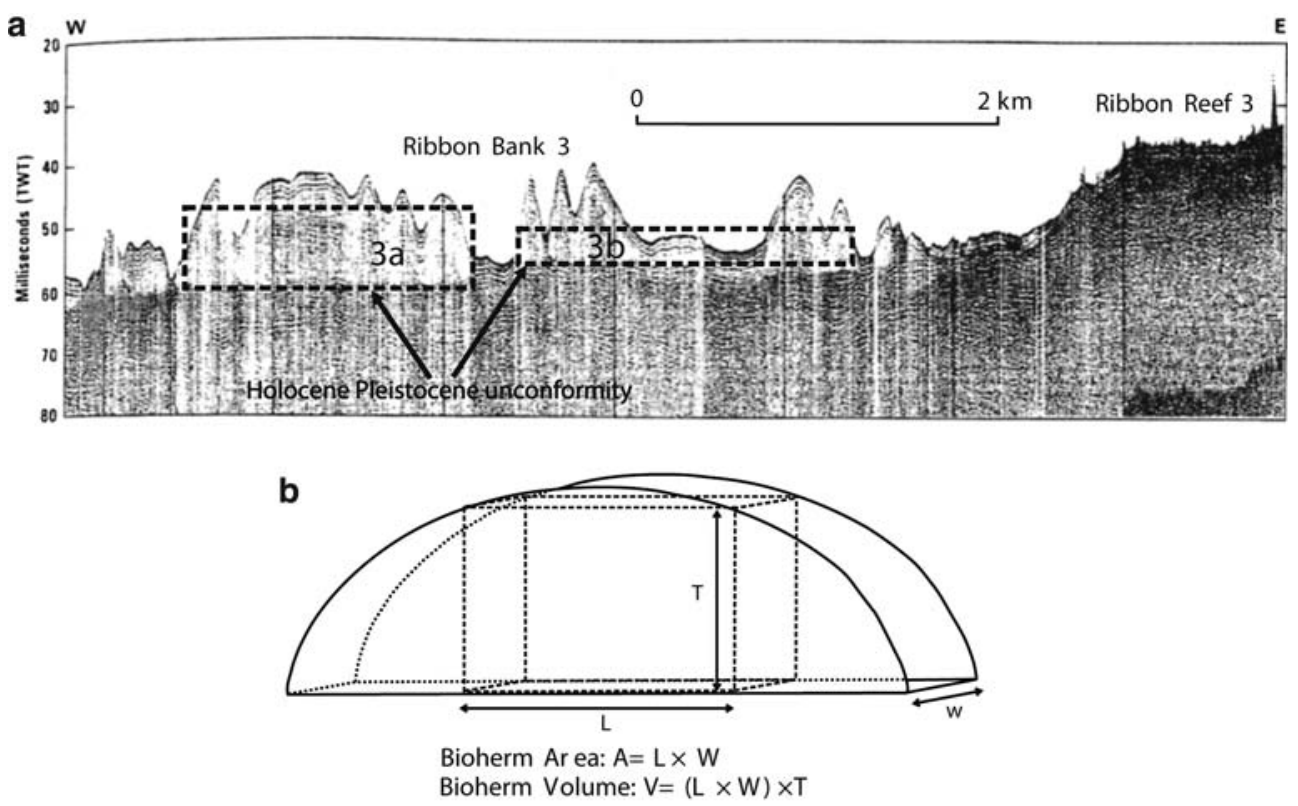

C
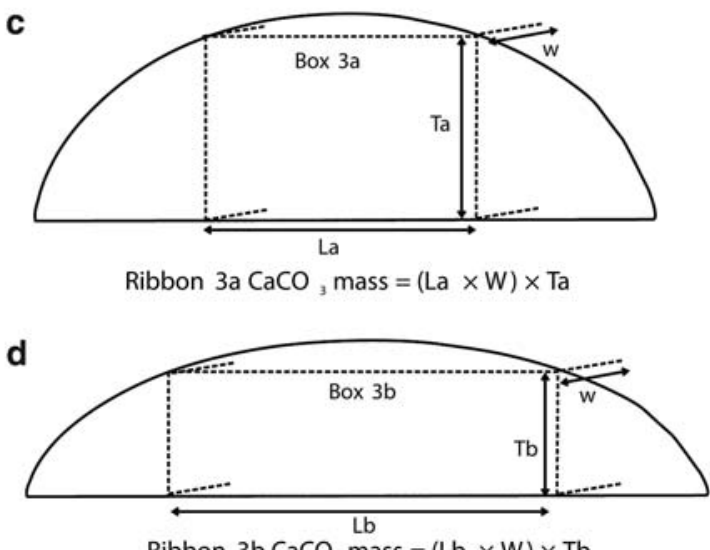

Ribbon $3 \mathrm{~b} \mathrm{CaCO}_{3}$ mass $=(\mathrm{Lb} \times \mathrm{W}) \times \mathrm{Tb}$ 
therefore it is assumed that the carbonate content of the bioherms is $75 \%$ throughout.

\section{Results}

Reef and bioherm calcium carbonate

This study estimates that the ribbon reefs of the Lizard Island and Cooktown regions cover areas of approximately 18.5 and $20.5 \mathrm{~km}^{2}$ and comprise approximately 0.52 and $0.92 \mathrm{Gt} \mathrm{CaCO}_{3}$, respectively (Table 2). The Halimeda bioherms of the Lizard Island and Cooktown regions cover areas of approximately 184 and $118 \mathrm{~km}^{2}$ and comprise approximately 2.06 and $0.86 \mathrm{Gt} \mathrm{CaCO}_{3}$, respectively (Table 3 ).

Thus, the ratio of ribbon reef to Halimeda bioherm $\mathrm{CaCO}_{3}$ is approximately $1: 4$ and $1: 1$ for the Lizard Island and Cooktown regions, respectively (Fig. 6; Table 4).

\section{Discussion}

Reefs versus bioherms

The Halimeda bioherms contain at least as much (and up to four times more) $\mathrm{CaCO}_{3}$ sediment as the adjacent ribbon reefs in the NGBR (Table 4). This finding is in agreement with assertions that Halimeda bioherms contain more carbonate sediment than the adjacent reef platforms (Flood 1984; Hillis-Colinvaux 1986b; Marshall and Davies 1988; Freile and Hillis 1997). The ratio of reefal to bioherm $\mathrm{CaCO}_{3}$ varies within the NGBR province from 1:1 in the Cooktown region to $1: 4$ in the Lizard Island region. The variation in the ratio is a consequence of the differences in the thicknesses and extent of the bioherms in the two regions. For example, in the Lizard Island region the bioherms form a series of

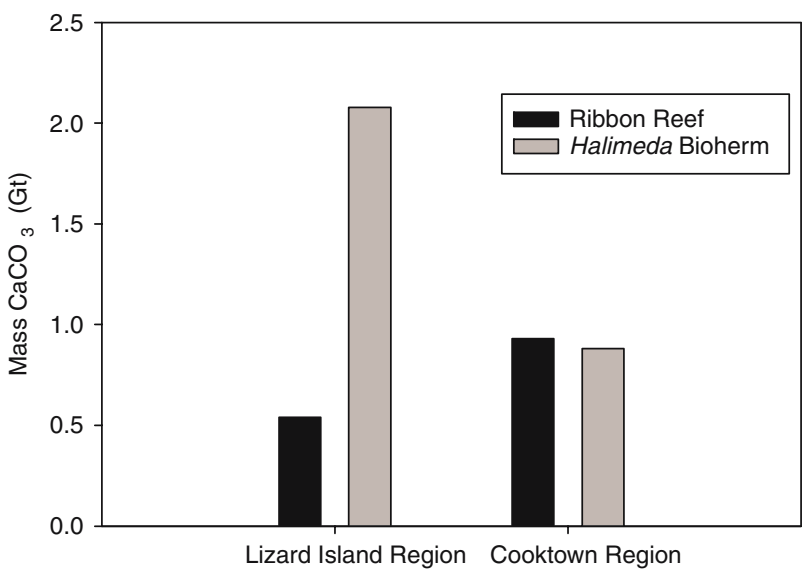

Fig. 6 Mass of carbonate sediments accumulated within the ribbon reefs and Halimeda bioherms of the Lizard Island and Cooktown regions of the Northern Great Barrier Reef large ridges which traverse most of the outer shelf, with an average thickness of $10 \mathrm{~m}$ (maximum $19 \mathrm{~m}$ ) and an area of at least $184 \mathrm{~km}^{2}$. Whereas the Cooktown region bioherms form discrete mounds behind each ribbon reef with maximum and minimum thickness of 11.25 and $3.75 \mathrm{~m}$, respectively, they cover a combined area of approximately $118 \mathrm{~km}^{2}$. The size differences in the Halimeda bioherms in these two regions is the result of the morphology of the shelf affecting the growth potential of the Halimeda. The formation of the bioherms is related to up-welling of nutrient-rich waters from the Coral Sea. The timing and amount of water intruding onto the shelf during the Holocene is controlled by sea level rise and the dimensions of the reef passes (bathymetry and width). For example, Wolanski et al. (1988) suggest that Halimeda Ribbon Bank 5 is small because it only received nutrients from one reef passage whereas the larger banks (bioherms) behind Ribbon Reefs 2, 3 and 4 were each fed by two passages (Fig. 3). The absence of bioherms behind Ribbon Reef 1, Lena Reef, Ribbon Reef 6 and Pearl Reef is attributed to the channels being are either too wide or too shallow to induce sufficient upwelling to support bioherm development. Wolanski et al. (1988) suggested that the presence of ribbon reefs at least $4 \mathrm{~km}$ long and reef passages $<1 \mathrm{~km}$ wide and 40-45 m deep are necessary for the development of bioherms.

\section{Halimeda distribution}

The extent of Halimeda bioherm formation within the GBR province has yet to be adequately assessed. Detailed bathymetric sampling has revealed that Halimeda sediments make up to $5-65 \%$ of the inter-reefal sediments on the outer shelf of the GBR province (Maxwell 1968). Drew and Abel (1983) estimated that $2,000 \mathrm{~km}^{2}$ of the GBR province seabed is carpeted with Halimeda vegetation. Standard monochrome aerial photographs of the far NGBR (between $12.3^{\circ} \mathrm{S}$ and $13.5^{\circ} \mathrm{S}$ ) reveal the presence of dark circular patches approximately $300 \mathrm{~m}$ in diameter. These patches were initially interpreted as submerged reefal shoals, however, it has also been suggested that they could be Halimeda bioherms (Hopley 1978; Drew and Abel 1988). Seismic profiling transects of the NGBR (from Lloyd Island to Hibernia Entrance and from Restoration Island to Second Small Reef) in the region adjacent to Portland Roads and the Lockhart River reveal the presence of substantial Halimeda bio-

Table 4 Mass of $\mathrm{CaCO}_{3}$ accumulated by the ribbon reefs and Halimeda bioherms of the Lizard Island and Cooktown regions during the Holocene

\begin{tabular}{llll}
\hline Region & $\begin{array}{l}\text { Reef } \\
\mathrm{CaCO}_{3}(\mathrm{Gt})\end{array}$ & $\begin{array}{l}\text { Halimeda } \\
\mathrm{CaCO}_{3}(\mathrm{Gt})\end{array}$ & $\begin{array}{l}\text { Ratio of } \\
\text { reef:Halimeda } \\
\mathrm{CaCO}_{3}\end{array}$ \\
\hline $\begin{array}{l}\text { Lizard Island } \\
\text { Cooktown }\end{array}$ & 0.52 & 2.06 & $1: 4$ \\
\hline
\end{tabular}


herms on the outer shelf in this region (J.S. Jell, personal communication). Given reports of luxuriant Halimeda meadows principally at 20-40 m below sea level on the GBR (Drew 1983; Drew and Abel 1985), Hillis (1997) suggested that it is likely that additional Halimeda bioherms will be discovered.

Previous studies have indicated that the Halimeda bioherms may have begun to develop prior to the initiation of reef colonization of topographic highs on the shelf (Marshall and Davies 1988). It has been suggested that the locus of carbonate deposition on the NGBR shelf shifted from bioherm development (between 10 and $8.5 \mathrm{kyr}$ BP) when the shelf was initially flooded, to coral reef development when the eroded karst remnants of the Pleistocene ribbon reefs were transgressed and served as sites for Holocene reef colonization (Hopley 1994). The common delay in reef colonization of newly flooded topographic highs within the NGBR is probably related to high nutrient levels which would have favoured Halimeda growth (Davies et al. 1985; Marshall and Davies 1988; Hopley 1994). It has been proposed that changes in oceanic circulation or climate then favoured the development of coral reefs, on topographic highs, between 8,000 and 4,000 years BP (Davies et al. 1985). Halimeda bioherm development may have been reduced during the main phase of reef growth. Once the Holocene ribbon reefs had attained a sufficient height in relation to sea level, the area behind the ribbon reefs would have again become sufficiently sheltered enough to allow Halimeda bioherm development which continues to this day (Davies and Marshall 1985; Marshall and Davies 1988; Hopley 1994). If this model of Holocene shelf evolution is correct, Halimeda calcification within the NGBR may have released a pulse of $\mathrm{CO}_{2}$ to the early Holocene atmosphere.

\section{Carbonate budget}

Rees (2006) estimated that the coral reefs of the GBR (North and Northeastern Australia) accumulated $1,709 \mathrm{Gt} \mathrm{CaCO}_{3}(205 \mathrm{Gt} \mathrm{C})$ over the last 10,000 years. This mass balance of $\mathrm{CaCO}_{3}$ was estimated using the reef area estimate of $4.492 \times 10^{4} \mathrm{~km}^{2}$ calculated using Spalding et al.'s (2001) reef area estimate for Australia minus the area of Ningaloo Reef, the Houtman Abrolhos Islands, Christmas Island and Cocos-Keeling Islands (Sheppard and Wells 1988). If it is assumed that $0.6 \mathrm{~mol}$ of $\mathrm{CO}_{2}$ is available for release to the atmosphere per mole of $\mathrm{CaCO}_{3}$ deposited in the marine environment (Ware et al. 1991; Zeebe and Wolf-Gladrow 2001), the Halimeda bioherms of the Lizard Island and Cooktown regions had the potential to release 0.54 and $0.23 \mathrm{Gt} \mathrm{CO}_{2}$ to the atmosphere during the last $10 \mathrm{kyrs}$, respectively.

Assuming that the conservative ratio of ribbon reef to Halimeda bioherm $\mathrm{CaCO}_{3}$ calculated here for the Cooktown region (1:1) holds true for the entire NGBR, it is possible to estimate the approximate mass of car- bonate sediments within the Halimeda bioherms of the whole NGBR. Using Kinsey and Hopley's (1991) estimate of the total area covered by the GBR ribbon reefs (approximately $1,081 \mathrm{~km}^{2}$ ) and conservatively assuming the thickness of the ribbon reefs to be $10 \mathrm{~m}$, this study estimates that the ribbon reefs and hence the Halimeda bioherms of the NGBR may have accumulated at least $32 \mathrm{Gt} \mathrm{CaCO}_{3}$ during the Holocene. Indeed Halimeda bioherms have been found to have similar accretion and production rate compared to coral reefs (Table 5). It is important to note that ribbon reefs are mainly restricted to the NGBR hence these calculations are restricted to the northern province of the GBR and that this estimate is confined to the Halimeda bioherms behind the ribbon reefs, it does not include Halimeda bioherms in the Swains Reef complex (Southern GBR).

While the mass of carbonate contained within the Halimeda bioherms of NGBR $\left(\sim 32 \mathrm{Gt} \mathrm{CaCO}_{3}\right.$; $3.9 \mathrm{Gt} \mathrm{C}$ ) is small in comparison to that contained within the reefs of the GBR as a whole $(1,709 \mathrm{Gt} \mathrm{Ca}$ $\mathrm{CO}_{3} ; 205 \mathrm{Gt} \mathrm{C}$ ) or globally (Table 6; Rees 2006) this perspective mis-represents the likely wider importance of Halimeda within the carbon budget because the true extent of this sedimentary facies is probably vastly underestimated (Table 6). It is important to note that Halimeda sediments contribute significantly to coral reef and lagoonal facies and can constitute up to $77 \%$ of lagoonal sediments on Pacific and Caribbean reefs (Hillis-Colinvaux 1980).

This study provides support for the contention that because bioherms have been found to produce and accumulate carbonate at similar rates to coral reefs, their importance in global carbon cycles is currently underestimated and merits further investigation. The global distribution and areal extent of Halimeda deposits are unknown, however the discovery of significant accumulations of Halimeda carbonate including; Miskito Channel (SW Caribbean Sea; a band $125 \mathrm{~km}$ long reaching thicknesses of $20-30 \mathrm{~m}$ ), K Bank (Java Sea; approximately $20-52 \mathrm{~m}$ thick, covering an area of at least $1,300 \mathrm{~km}^{2}$ ) and Big Bank Shoals (Timor Sea; a series of 13 submerged banks range from 0.05 to $40 \mathrm{~km}^{2}$ with thicknesses up to $55 \mathrm{~m}$ ), requires that their contribution to the global carbonate budget be better quantified (Roberts et al. 1987a; Hine et al. 1988; Heyward et al. 1997). If the ratio of Halimeda bioherm to coral reef carbonate on the shelf of the NGBR established here is even partially applicable globally then the accurate assessment of Halimeda distribution, through seismic profiling and vibrocoring, is a prerequisite to a comprehensive understanding of the marine carbon cycle.

This study estimates the ratio of reefal to Halimeda bioherm $\mathrm{CaCO}_{3}$ within the Northern GBR to fall somewhere in the range $1: 1-1: 4$. Assuming that thick emergent areas of coral reef covers approximately $300 \times 10^{3} \mathrm{~km}^{2}$ globally, Halimeda bioherm carbonate, of Holocene age, could rival the total carbonate derived from Holocene coral reefs alone (Spalding et al. 2001). 
Table 5 Comparison of Halimeda and coral reef productivity and accumulation rates during the Holocene

\begin{tabular}{|c|c|c|c|}
\hline Location & Accretion rate $\left(\mathrm{m} \mathrm{kyr}^{-1}\right)$ & Reference & Year \\
\hline \multicolumn{4}{|l|}{ Halimeda } \\
\hline NGBR Cooktown Big Bank bioherms & $0.75-2$ & Marshall and Davies & 1988 \\
\hline NGBR Lizard Island bioherm core $92^{\mathrm{a}}$ & 0.22 & Orme & 1985 \\
\hline SGBR Swains reef bioherm ${ }^{\mathrm{a}}$ & $2-3.5$ & Searle and Flood & 1988 \\
\hline K Bank bioherm, Java Sea ${ }^{\mathrm{a}}$ & $1.2-5.9$ & Roberts et al. & $1987 \mathrm{a}$ \\
\hline Western Great Bahama bank ${ }^{\mathrm{b}}$ & $2-4$ & Freile et al. & 1995 \\
\hline Bight of Abaco, Bahamas, lagoon ${ }^{\mathrm{b}}$ & $2-3$ & Neumann and Land & 1975 \\
\hline \multicolumn{4}{|l|}{ Coral reef } \\
\hline NGBR Lizard Island ${ }^{\mathrm{a}}$ & 1.1 & Rees & 2006 \\
\hline NGBR Macgillivray reef ${ }^{a}$ & $1.4-1.9$ & Rees & 2006 \\
\hline NGBR Yonge ribbon reef ${ }^{c, d}$ & 15.8 & Hopley & 1994 \\
\hline NGBR Ribbon reef $5^{\mathrm{a}, \mathrm{c}}$ & $1.3-14.2$ & Davies et al. & 1973 \\
\hline GBR windward reefs & $4-6$ & Davies and Hopley & 1983 \\
\hline GBR reefs ${ }^{\mathrm{a}, \mathrm{c}}$ & $1-4.4$ & Rees & 2006 \\
\hline Global reef $f^{\mathrm{a}, \mathrm{c}}$ & 1.16 & Rees & 2006 \\
\hline Location & Productivity $\left(\mathrm{kg} \mathrm{CaCO} \mathrm{m}^{-2}\right.$ year $\left.^{-1}\right)$ & Reference & Year \\
\hline \multicolumn{4}{|l|}{ Halimeda } \\
\hline GBR & 2.2 & Drew & 1983 \\
\hline Moorea Island lagoon, Tahiti ${ }^{\mathrm{e}}$ & 2.3 & Freile et al. & 1995 \\
\hline Western Great Bahama Bank ${ }^{\mathrm{b}, \mathrm{f}}$ & 2.4 & Freile and Hillis & 1997 \\
\hline Pico Feo, San Blas, Panama ${ }^{b}$ & 2.3 & Freile and Hillis & 1997 \\
\hline \multicolumn{4}{|l|}{ Coral reef } \\
\hline Seaward reef flat ${ }^{\mathrm{e}}$ & 4 & Smith and Kinsey & 1976 \\
\hline GBR reefs $\mathrm{e}^{\mathrm{e}}$ & 2.4 & Kinsey and Hopley & 1991 \\
\hline GBR ribbon reefs ${ }^{\mathrm{e}}$ & 3 & Kinsey and Hopley & 1991 \\
\hline Lizard Island reef $^{\mathrm{e}}$ & 4 & LIMER & 1975 \\
\hline
\end{tabular}

GBR Great Barrier Reef, NGBR Northern Great Barrier Reef, $S G B R$ Southern Great Barrier Reef

${ }^{a}$ Holocene mean accretion rates calculated from radiometrically dated cores

${ }^{b}$ Estimated from present day values biomass, percent cover, density and crops per year

${ }^{c}$ Mean Holocene accretion rates

${ }^{\mathrm{d}}$ Estimated from seismic profile thicknesses and assumed date of transgression (10 kyr before present)

${ }^{\mathrm{e} E s t i m a t e d ~ u s i n g ~ a l k a l i n i t y ~ a n o m a l y ~ t e c h n i q u e ~}$

${ }^{\mathrm{f}}$ Estimated by extrapolating modern productivity values into Holocene

Table 6 Comparison of Halimeda carbon mass balance with other natural reservoirs during the Holocene (adapted from Rees 2006)

\begin{tabular}{|c|c|c|c|}
\hline Reservoir & Mass carbon (Gt) & Reference & Year \\
\hline Present day atmosphere as $\mathrm{CO}_{2}$ & 720 & Powlson & 2005 \\
\hline Deep ocean dissolved inorganic carbon & 38,000 & Sigman and Boyle & 2000 \\
\hline Sediments and crust $(\mathrm{Ca}, \mathrm{Mg}) \mathrm{CaCO}_{3}$ & $48,000,000$ & Sigman and Boyle & 2000 \\
\hline Terrestrial & 2,100 & Sigman and Boyle & 2000 \\
\hline Present day soil reservoir (organic carbon) & 1,500 & Powlson & 2005 \\
\hline Present day carbon in vegetation & 600 & Powlson & 2005 \\
\hline Global coral reef $\mathrm{CaCO}_{3}$ & 956 & Rees & 2006 \\
\hline GBR coral reef $\mathrm{CaCO}_{3}$ & 205 & Rees & 2006 \\
\hline Global Halimeda $^{\mathrm{a}}$ & 576 & Hillis & 1997 \\
\hline Global Halimeda bioherms ${ }^{\mathrm{b}}$ & 180 & Hillis & 1997 \\
\hline NGBR Halimeda bioherms ${ }^{\mathrm{c}}$ & 3.9 & This study & \\
\hline NGBR coral ribbon reefs ${ }^{c}$ & 3.9 & This study & \\
\hline
\end{tabular}

${ }^{\mathrm{a}}$ Carbon in Halimeda sediments, including bioherms, reef lagoons, ridge, fore reefs, reef slopes, banks and bays

${ }^{\mathrm{b}}$ Carbon in Halimeda bioherm sediments

${ }^{c}$ Estimated using Kinsey and Hopley's (1991) ribbon reef area of $1,081 \mathrm{~km}^{2}$ and the ratio of coral reef: Halimeda bioherm carbonate within the Northern Great Barrier Reef (NGBR) of 1:1 established in this study

The areal extent of the Halimeda bioherms needs to be better quantified before a confident mass balance for neritic carbonate of Holocene age can be established for the NGBR. However, if the ratio of Halimeda bioherm to coral reef carbonate on the shelf of the NGBR established here is even partially applicable globally then this study concludes that current global budgets for shallow water $\mathrm{CaCO}_{3}$ sediments, that are based on coral reefs alone, are significantly underestimated.

Acknowledgments This research has been supported by the National Environment Research Council; the Royal Society and 
the Earth and Marine Sciences Department, Australian National University, Canberra. We would especially like to thank John Davis for assisting in field expedition operations, Dr John Jell for supplying various seismic profiles of the GBR, the Lizard Island Research Station and Staff (particularly Bob Lamb for his patience and enthusiasm during fieldwork attempts), the Australian Museum and the GBR Marine Park Authority.

\section{References}

Ball SM, Pollard WD, Roberts JW (1977) Importance of phylloid algae in development of depositional topography-reality or myth. In: Frost SH, Weiss MP, Saunders JB (eds) Reefs and related carbonates - ecology and sedimentology. Am Assoc Pet Geol Bull 4:239-259

Chappell J, Chivas A, Wallensky E, Polach HA, Aharon P (1983) Holocene paleo-environmental changes, central to north Great Barrier Reef inner zone. BMR J Aust Geol Geophys 8:223-235

Davies PJ, Marshall JF (1979) Aspects of Holocene reef growthsubstrate age and accretion rate. Search 10:276-279

Davies PJ, Marshall JF (1980) A model of epi-continental reef growth. Nature 287:37-38

Davies PJ, Marshall JF (1985) Halimeda bioherms - low energy reefs, northern Great Barrier Reef. Proc 5th Int Coral Reef Congr 5:1-7

Davies PJ, Hopley D (1983) Growth facies and growth rates of Holocene reef in the Great Barrier Reef. BMR J Aust Geol Geophys 8:237-251

Davies PJ, Marshall JF, Radke B (1973) Growth rate: reefs of the central and northern province. Proceedings inaugural Great Barrier Reef conference, Townsville. JCU, Townsville, Australia, pp 95-98

Davies PJ, Marshall JF, Thom BG, Harvey N, Short AD, Martin K (1977) Reef development Great Barrier Reef. Proc 3rd Int Coral Reef Symp 2:332-337

Davies PJ, Marshall JF, Hopley D (1985) Relationships between reef growth and sea level in the Great Barrier Reef. Proc 5th Int Coral Reef Congr 3:95-103

Drew EA (1983) Halimeda biomass, growth rates and sediment generation on reefs in the central GBR province. Coral Reefs 2:101-110

Drew EA (1993) Production of geological structures by the green alga Halimeda. South Pac Underwater Medicine Society Journal 23(2):93-102

Drew EA, Abel KM (1983) Biology and sedimentology and geography of the vast inter-reefal Halimeda meadows within the Great Barrier Reef province. Coral Reefs 2:101-110

Drew EA, Abel KM (1985) Biology, sedimentology and geography of the vast inter-reefal Halimeda meadows within the Great Barrier Reef province. Proc 5th Int Coral Reef Congr 5:15-20

Drew EA, Abel KM (1988) Studies on Halimeda I. The distribution and species composition of Halimeda meadows throughout the GBR province. Coral Reefs 6:195-205

Elliot GF (1965) The interrelationships of some Cretaceous Codiaceae (calcareous algae). Palaeontology 8(2):199-203

Flood PG (1984) A geological guide to the northern Great Barrier Reef. Australasian Sedimentologists group field guide series, No. 1. Geological Society of Australia, Sydney

Flood PG, Orme GR (1988) Mixed siliciclastic/carbonate sediments of the northern Great Barrier Reef province, Australia. In: Doyle LJ, Roberts HH (eds) Carbonate-clastic transitions, developments in sedimentology, vol 42. Elsevier, Amsterdam, pp 175-205

Freile S, Hillis I (1997) Carbonate productivity by Halimeda incrassate in a land proximal lagoon, Pico Feo, San Blas, Panama. Proc 8th Int Coral Reef Symp 1:767-772

Freile D, Milliman JD, Hillis L (1995) Leeward bank margin Halimeda meadows and draperies and their sedimentary importance on the western Great Bahama Bank slope. Coral Reefs 14:27-33
Harris PT, Pattiaratchi CB, Keene JB, Dalrymple RW, Gardner JV, Baker EK, Cole AR, Mitchell D, Gibbs P, Schroeder WW (1996) Late quaternary deltaic and carbonate sedimentation in the Gulf of Papua foreland basin: response to sea-level change. J Sediment Res A 66:4801-4819

Harvey N (1977a) Application of shallow seismic refraction techniques to coastal geomorphology: a coral reef example. Catena $4: 333-339$

Harvey N (1977b) The identification of subsurface disconformities of the Great Barrier Reef, Australia between $14^{\circ} \mathrm{S}$ and $17^{\circ} \mathrm{S}$, using shallow seismic refraction techniques. Proc 3rd Int Coral Reef Symp 2:45-51

Heyward A, Pinceratto E, Smith LD (1997) Big Bank Shoals of the Timor Sea: an environmental resource atlas. Australian Institute of Marine Science and BHP Petroleum, Townsville, Australia

Hillis L (1997) Coralgal reefs from a calcareous green alga perspective and a first carbonate budget. Proc 8th Int Coral Reef Symp 1:761-766

Hillis-Colinvaux L (1980) Ecology and taxonomy of Halimeda: primary producer of coral reefs. Adv Mar Biol 17:1-327

Hillis-Colinvaux L (1986a) Deep water populations of Halimeda in the economy of an Atoll. Bull Mar Sci 38:155-169

Hillis-Colinvaux L (1986b) Halimeda growth and diversity on the deep fore-reef of Enewetak Atoll. Coral Reefs 5:19-21

Hine AC, Hillock P, Harris MW, Mullins HT, Belknap DF, Jaap WC (1988) Halimeda bioherms along an open seaway: Miskito Channel, Nicaraguan Rise, SW Caribbean Sea. Coral Reefs $6: 173-178$

Hopley D (1977) The age of the outer Ribbon Reef surface, Great Barrier Reef, Australia: implications for hydrostatic models. Proc 3rd Int Coral Reef Symp 2:23-28

Hopley D (1978) Geomorphology of the reefs and reef islands Great Barrier Reef north of Lizard Island. In: Workshop on northern section of Great Barrier Reef. Great Barrier Reef Marine Park Authority, Townsville, pp 129-252

Hopley D (1982) The geomorphology of the Great Barrier Reef: quaternary development of coral reefs. Wiley, New York

Hopley D (1994) Continental shelf reef systems. In: Carter RWG, Woodroffe CD (eds) Coastal evolution, late quaternary shoreline morphodynamics. Cambridge University Press, Cambridge, pp 303-340

International Consortium for Great Barrier Reef Drilling (2001) New constraints on the origin of the Australian Great Barrier Reef: results from an international project of deep coring. Geology 29:483-486

Johnson JH (1969) A review of the lower Cretaceous algae. Professional Contribution Colarado School of Mines, No 6. Golden, Colorado

Kinsey DW (1979) Carbon turnover and accumulation by coral reefs. PhD thesis, University of Hawaii, Honolulu, p 248

Kinsey DW, Hopley D (1991) The significance of coral reefs as global carbon sinks - response to greenhouse. Palaeogeogr Palaeoclimatol Palaeoecol (Global and Planetary Change Section) 89:363-377

Kirkland BL, Moore CH Jr, Dickson JAD (1993) Well preserved aragonite algae (Eugonophyllum U'doteaceae) form the Pennsylvanian Holder Formation, Sacramento Mountains, New Mexico. Palaios 8:111-120

LIMER (Barnes DJ, Caperon J, Cox TJ, Crossland CJ, Davies PJ, Devereux M, Hamner WM, Jitts HR, Kinsey DW, Knauer GA, Lundgren JA, Olafson R, Skyring GW, Smith DF, Webb KL, Wiebe WJ) (1975) LIMER expedition 1975 metabolic processes of coral reef communities at Lizard Island, Queensland. Search 7:463-468

Marshall JF, Davies PJ (1988) Halimeda bioherms of the Northern Great Barrier Reef. Coral Reefs 6:139-148

Maxwell WGH (1968) Atlas of the Great Barrier Reef. Elsevier, Amsterdam

Maxwell WGH (1973) Sediments of the Great Barrier Reef. In: Jones OA, Endean R (eds) Biology and geology of coral reefs. Geology, vol 1, chap 10. Academic, New York, pp 299-345 
Milliman JD (1993) Production and accumulation of calcium carbonate in the ocean: budget of a non-steady state. Global Biogeochem Cycles 7:927-957

Neumann AC, Land LS (1975) Lime mud deposition and calcareous algae in the Bight of Abaco, Bahamas: a budget. J Sediment Petrol 45:763-786

Orme GR (1983) Shallow structure and lithofacies of the Northern Great Barrier Reef. In: Baker JT, Carter RM, Sammarco PW, Stark KP (eds) Proc Great Barrier Reef Conf. JCU, Townsville, pp $135-142$

Orme GR (1985) The sedimentological importance of Halimeda in the development of back reef lithofacies, Northern Great Barrier Reef (Australia). Proc 5th Int Coral Reef Symp 5:31-37

Orme GR, Flood PG (1977) The geological history of the Great Barrier Reef: a reappraisal of some aspects in the light of new evidence. Proc 3rd Int Coral Reef Symp 2:37-43

Orme GR, Flood PG (1980) Sedimentation in the Great Barrier Reef province, adjacent bays and estuaries. In: Henderson RA, Stephenson PJ (eds) The geology and geophysics of Northeastern Australia. Geological Society of Australia Inc., Queensland Division, pp 419-434

Orme GR, Salama MS (1988) Form and seismic stratigraphy of Halimeda banks in part of the Northern Great Barrier Reef Province. Coral Reefs 6:131-137

Orme GR, Flood PG, Sargent GEG (1978) Sedimentation trends in the lee of outer (ribbon) reefs, northern region of the Great Barrier Reef province. Philos Trans R Soc Lond A 291:85-99

Phipps CVG, Roberts HH (1988) Seismic characteristics and accretion history of Halimeda bioherms on Kalukalukuang Bank eastern Java Sea (Indonesia). Coral Reefs 6:149-159

Phipps CVG, Davies PJ, Hopley D (1985) The morphology of Halimeda banks behind the GBR east of Cooktown, Qld. Proc 5th Int Coral Reef Symp 5:27-30

Powlson D (2005) Will soil amplify climate change? Nature 433:204-205

Rees SA (2006) Coral reefs of the Indo-Pacific and changes in global Holocene climate. PhD thesis, University of Southampton, UK, p 188

Rees SA, Opdyke BN, Wilson PA, Fifield LK (2005) Coral reef sedimentation on Rodrigues and the Western Indian Ocean and its impact on the carbon cycle. Philos Trans R Soc Lond A 363:101-120

Ridgwell AJ, Zeebe RE (2005) The role of the global carbonate cycle in the regulation and evolution of the Earth system. Earth Planet Sci Lett 234:299

Roberts HH, Phipps CV (1988) Proposed oceanographic controls on modern Indonesian Reefs: a turn-off/turn-on mechanism in a monsoonal setting. Proc 6th Int Coral Reef Symp 3:529-534
Roberts HH, Phipps CV, Effendi L (1987a) Halimeda bioherms of the eastern Java Sea, Indonesia. Geology 15:371-374

Roberts HH, Phipps CV, Effendi L (1987b) Morphology of large Halimeda bioherms, eastern Java Sea (Indonesia): a side scan sonar study. Geo-Mar Lett 7:7-14

Roberts HH, Aharon P, Phipps CV (1988) Morphology and sedimentology of Halimeda bioherms from the eastern Java Sea (Indonesia). Coral Reefs 6:161-172

Ryan DA, Opdyke BN, Jell JS (2001) Holocene sediments of Wistari Reef towards a global quantification of coral reef related neritic sedimentation in the Holocene. Palaeogeogr Palaeoclimatol Palaeoecol 175:1-12

Searle DE, Flood PG (1988) Halimeda bioherms of the Swain Reefs-Southern Great Barrier Reef. Proc 6th Int Coral Reef Symp 3:139-144

Sheppard CRC, Wells SM (1988) Coral reefs of the world, vol 2. Indian Ocean, Red Sea and Gulf, UNEP Regional Seas Directories and Bibliographies. IUCN/UNEP Nairobi, Gland, Switzerland

Sigman DM, Boyle EA (2000) Glacial/interglacial variations in atmospheric carbon dioxide. Nature 407:859-869

Smith SV (1978) Coral reef area and the contributions of reefs to the processes and resources of the world's oceans. Nature 273:225-226

Smith SV, Kinsey DW (1976) Calcium carbonate production, coral reef growth and sea level change. Science 194:937-939

Spalding MD, Ravillious C, Green EP (2001) World atlas of coral reefs. University of California Press, Berkeley

Steneck RS, Testa V (1997) Are calcareous algae important to reefs today or in the past? Proc 8th Int Coral Reef Symp 1:685-688

Stoddart DR, McLean RF, Scoffin TP, Thom BG, Hopley D (1978) Evolution of reefs and islands, Northern Great Barrier Reef: synthesis and interpretation. Philos Trans R Soc Lond B 284:149-159

Thom BG, Chappell J (1975) Holocene sea-levels relative to Australia. Search 6:90-93

Ware JR, Smith SV, Reaka-Kudla ML (1991) Coral reefs: sources or sinks of atmospheric $\mathrm{CO}_{2}$. Coral Reefs 1:127-130

Wolanski EJ, Drew EA, Abel KM, O'Brien J (1988) Tidal jets, nutrient upwelling and their influence on the productivity of the alga Halimeda in the Ribbon Reefs, Great Barrier Reef. Estuar Coast Shelf Sci 26:169-201

Wray JL (1977) Calcareous algae, developments in palaeontology and stratigraphy, vol 4. Elsevier, New York

Zeebe RE, Wolf-Gladrow DA (2001) $\mathrm{CO}_{2}$ in seawater: equilibrium, kinetics, isotopes. Elsevier Oceanography Series, Amsterdam 